\title{
Internalizing a Discourse: Reading Shauna Singh Baldwin's What the Body Remembers
}

\author{
Brahmjot Kaur \\ Research Scholar \\ Department of English and MEL \\ University of Lucknow \\ Lucknow, UP, India \\ brahmjotkaur0710@gmail.com
}

\begin{abstract}
Shauna Singh Baldwin's novel What the Body Remembers is mostly remembered as a Partition novel. No doubt, one of the best Partition novels, the novel is also successful in exemplifying how grand-narratives bring us into adherence and train our minds to pass on the same to our coming generations. Baldwin's characters are prisoners to these grand-narratives but they hardly realize that, and thereby make no effort to shirk away from these beliefs. This paper endeavors to study these characters in the light of this socializing process, and the transformation that it brings.
\end{abstract}

Keywords- Discourse, Patriarchy Internalize, Colonizer

A discourse is an utterance on a particular subject. The Oxford dictionary defines it as a "communication, a treatise or a lecture" (192). A discourse on a subject may vary from person to person, but it is usually found that a group of people share their perspective on a particular topic, 
and thereby their discourse is similar. This discourse thereby is a construct and cannot be regarded as the ultimate and only truth, for by changing the standpoint, the perspective and the discourse both may alter. But this discourse of people in power is imposed on the oppressed groups. These hegemonic groups internalize their discourse and want the marginalized sects to also internalize their discourse. When such discourse, is internalized it becomes a grandnarrative, and is believed and propagated and passed on through centuries, through sects, through generations as the only truth. It takes a lot of effort to subvert a grand narrative by exposing its status of being a construct and not a pre-ordained truth. Various such grand-narratives rule our society and various movements too have originated with the aim of combating this politics of hegemonic discourse.

The patriarchal discourse and its grand narrative of patriarchy has been a part of human society since early times. It's almost impossible to trace its origins, but one knows that for centuries reformers have been trying to subvert it. This discourse is so deeply embedded and internalized that even today one finds many females being perpetrators of it, besides just males. Likewise, the Eurocentric discourse initiated by the Europeans, chiefly the British, to legitimize their supremacy and their domination of the East gradually got internalized and even during fervent freedom struggle, after bearing inhuman atrocities, some natives shared pro-British sentiments. This in brief is the politics of grand-narratives, which dominate mini-narratives. Post-modern age is the age of mini-narratives, when the center is being shifted to the narrative of the marginalized. These narratives are trying to revert back, and dismantle the authority of grandnarrative by challenging their authenticity. This shift of agency to the oppressed is the main aim of Feminist discourse and Postcolonial discourse among various others. I have chiefly mentioned these two because the novel under study chiefly deals with them. 
Shauna Singh Baldwin's novel What the Body Remembers is a gripping tale of two wives of a government servant during the last leg of British colonization, ending in the tragic Partition of the Nation. Most of the characters in the novel are those who are believers and perpetrators of either one of these discourses of Patriarchy and European hegemony, sometimes of both. With personal experience only one character achieves release from them and it is her voice of truth, of 'Satya', exposing the vacuity of these overarching, canonized discourses that reverberates throughout the novel, initially in her physical self and after her death echoing within other characters.

The chief female protagonist of the novel is Roop. The youngest daughter of Bachan Singh, she is beloved of everyone in her family. She is spirited, lively, inquisitive, and courageous besides being beautiful. Early in her childhood she loses her mother, and soon society begins to socialize her into the stereotypical gender role defined for women. She is not allowed to be present in her mother's last rites because "this is men's work" (Baldwin 35) Roop internally questions each dictate of society but her surroundings give her no answers. She is pained when her initially secular father, becomes rigid and forbids any other religious practice in the house except those validated by Sikhism, but her father does not notice her aunt RevatiBhua's pain, because "all men see their women from the corner of each eye”( Baldwin 43) , thereby remaining indifferent to their emotions. Her maternal grandmother is pitied for she outlives her husband and her daughter, "A husbandless, childless woman; such terrible kismat ...what she must have done in her past life!"(Baldwin56). Due to some ailment Roop's hearing is impaired. She is deafened from one ear, and her father makes her promise to practice and keep it a secret all her life, for any knowledge of such impairment would lessen her chances of a good future. Roop takes part in 'Swadeshi' movement out of her desire to burn her mother's shawl and 
in some way perform her mother's last rites. Roop boldly asks her father to educate her in a school where children sit on benches and not on floor. Roop is adventurous and on her brother's marriage insists on being allowed to go back home alone on her pony. Roop is confident and proud of her beauty, which will she believes lead her to a wealthy match with all luxuries. Roop thereby dismisses every advice to learn cooking. This spirited individual is gradually ta med by society. She is socialized and made to conform and fit in, thereby curbing her independent spirit. Lajobhua's three laws- to always say“only achchaji, hanji and yes-ji” (Baldwin 76), to always speak softly, and to never get angry, stay with Roop all her life. It is in conformity to these laws that she sacrifices her first two babies- daughter Pavan and son Timcu, and gives them to Satya. In severe pain of losing her babies she is unable to vent her anger, her need, and her plight. Even when Satya threatens to poison her, she is unable to fight for her safety, rather runs back to her father's home. Madani is asked by everyone to hide her teeth, and smile carefully, to prevent her in-laws from noticing her large teeth. The shallowness of society and its beliefs are instilled into innocent minds. By the time Roop matures, she has two people Kusum and Madani as role models before her. Madani and Kusum, both bear sons for their husbands, both are "sweetsweet", "good-good"(Baldwin 83) docile women, living according to patriarchal dictates, and believing them to be the only correct way of life. Roop too is trampled and the child bearing function of a female, becomes for her the prime role after marrying Sardarji. She is for Sardarji, his "koel”(Baldwin 270). Somewhere one is reminded of Henrik Ibsen's Torvald calling Nora his “skylark" (Ibsen 9).Roop adorns herself with ornaments and is an object of pleasure and a child bearing machine for Sardarji. What role Satya could not fulfill, Roop is brought in to fulfill. Hardly does Sardarji realize her pain on parting with her kids, and later when she leaves home, fearing being poisoned by Satya. At home, Roop is coerced to go back, for there is no place for a 
married girl in her parents' house."Papaji will not protect her. His duty to Roop ended the day of her marriage..." (Baldwin 262). The Roop of her childhood days is lost to the norms of society. She socializes her daughter Pavan in the same way as her world socialized her. No sooner does she find out Pavan's eye defect, than she begins to teach her to lower her eyes when talking to others, in order to prevent the world from noticing her weakness. "Ay, learn what women are for!'(Baldwin 231) She slaps her often to bring her to conform, "like Revati Bua's slap...like so many dhaaps that women need every so often for-their-own-good.” (Baldwin 231) She tries learning English to feel herself a part of the society, when Sardarji takes her to English circles. It is years later during the havoc of Partition that we again see the same Roop, we see her fighting the hooligans who come to assault her, we see her venting her anger, using her wits, and even independently looking for her missing husband for days. Roop's life is an example of Beauvoir's assertion that "one is not born but rather becomes a woman.”(Beauvoir 283)

Sardarji is a government servant. He is an engineer in the Irrigation Department. He is one of those Indians who have internalized the Eurocentric discourse and believe in the supremacy of the British and hail the Empire for everything they do. According to him the English are indispensable. He never thought that the British would leave, and did not believe that India could function properly without the British. He is an emblem of an Anglicized Indian, and also a male chauvinist. In his view a man is "A competent being, able to guide and speak for those beneath him, especially the incompetent. Women for instance...naturally" (Baldwin224). The man woman binary is absolute for him. Women are incompetent and only feel, "the world would be better if only women were more objective, that is their basic problem" (Baldwin273). When Roop goes to PariDarwaza it is hard for him to believe for according to him Roop was given every luxury that she could ever need, and he brought her presents, and there could be no 
cause for sorrow. He is worried only about his son for "the girl is nothing" (Baldwin 270). It is just for the sake of his status pride amongst a Muslim majority people that he complies with Bachan Singh and Jeevan's demands, and decides to shift to Lahore with Roop and children, leaving behind Satya in Rawalpindi. Though his notions about women never change, but the havoc of Partition does bring to him the ideas that Satya upheld.

"Surely there will come a time when just being can bring izzat in return, when a woman will be allowed to choose her owner, when a woman will not be owned, when love will be enough payment for marriage, children or no children, just because her Shakti takes shape and walks the world again" (Baldwin310) Satya's life brought her this enlightenment and freed her from the clutches of patriarchal discourse. Born to a family of freedom fighters, she had much early in life learnt and imbibed patriotism and love for native culture. She always kept telling Sardarji of the shrewdness of colonizers, never attempted to learn the "git-mit"(Baldwin 296) or mimic the colonizer and was even free from the religious bias or the Hindu-Muslim divide that cut the nation into two. Satya despite all treatments, all amulets and prayers, could not bear a child for Sardarji. While Sardarji's desperation soared, she began to realize that her individuality, her entire being was being belittled due to her incapacity of bearing a child. She hated Roop, treated her no less than a servant, convinced Sardarji to make Roop give her first born child to her, and later even her first son to her, Satya even scared Roop of poisoning and made her flee home in Sardarji's absence. Sardarji's decision to leave her alone in Rawalpindi breaks her strength completely. Satya who is the most intelligent and progressive of all characters decides to give up her life, and poisons herself leading to tuberculosis and her death. Even though she dies the, 'Satya' - truth that she always voiced stays alive after her. During every weak moment of life, Sardarji and Roop are reminded of her fearless views. 
All other characters likewise are prisoners of grand-narratives. Bachan Singh, Roops father keeps telling Roop to be docile and submissive. For him as Kusum says, "izzat is bigger" (Baldwin 264) in society is more important than his daughter. In his eyes, his daughter-in-law Kusum is better than Roop because she never questions, never refuses and successfully bears sons. After once witnessing the Arya Samajis bullying a Sikh, Bachan Singh strongly condemns everyone from practicing anything except Sikhism. He narrates the tragedy of Jallianwala Bagh to Jeevan and instills in him the importance of learning English. Post-partition, Bachan Singh is left alone since Kusum is brutally murdered by Muslim rioters, and Jeevan is posted somewhere else. True to old norms he prefers to stay alone than staying in a married daughter's house. RevatiBhua is an unmarried aunt, who is pitied by everyone, and plays a major role in Roop's upbringing after her mother's death. In order to bring conformity, RevatiBhua always tells Roop that she saw her mother in her dream and through the dead mother conveys to Roop the dictates of patriarchy expected from her. Gujri, a house-help, likewise is a socializing agent in Roop and Madani’s lives. Roop's grandmother has more rigidly internalized patriarchal discourse. She is seen to be in favor of strict purdah and even forbids Bachan Singh from taking her daughter to the hospital for her treatment, due to which she dies post-partum. Jeevan has little role in the story. He most importantly advises Roop to learn English to gain supremacy over Satya. We hardly get to know much about his views but it seems he is an image of Bachan Singh.

These characters' lives, chiefly of Roop, Sardarji and Satya, are examples of how hegemonic powers bring us to adherence by training and molding our minds likewise. Hardly does an individual realize the distinction between his true self and what he is turned into. His beliefs become one with those of the overpowering grand-narrative. There are very few whose experiences or surroundings provide them an insight and release from the clutches of these 
grand-narratives. Julia Chisteva's concept of performativity too comes to mind while reading the novel, Roop being best example of the same.The novel frequently brings to us the idea "What we women are for" (Baldwin 32) in context of child bearing, gradually training minds into that performance, and other gender roles. Lastly, the title of the novel is likewise very apt. The body remembers its experiences of scolding from elders, their chiding and gradually learns to fear public opinion. The body remembers its humiliations, and honors and thereby repeats those behaviors which have led to positive reinforcements. And also the body of these characters remembers the trauma and violence of Partition that they witnessed. 


\section{Works Cited}

Baldwin, Shauna Singh. What the Body Remembers. Anchor, 2001.

Beauvoir, Simone de.The Second Sex.Translated by Constance Borde and Sheila Malovany Chevallier, Alfred A. Knopf, 2010.

Ibsen, Henrik. A Doll's House.Maple Press, 2011.

Oxford Mini Dictionary and Thesaurus.Edited by Charlotte Livingstone.Oxford University Press, 2011. 